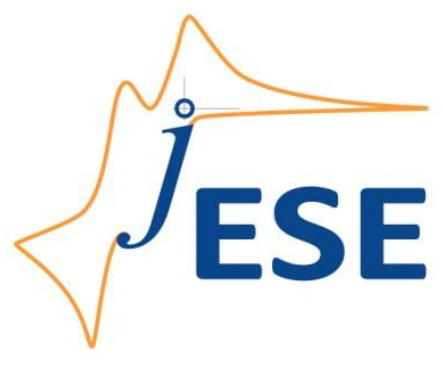

Open Access : : ISSN 1847-9286

www.jESE-online.org

Original scientific paper

\title{
Electrochemical treatment of Acid Red 1 by electro-Fenton and photoelectro-Fenton processes
}

\author{
Camilo González-Vargas, Ricardo Salazar ${ }^{\bowtie}$ and Ignasi Sirés*: \\ Laboratorio de Electroquímica Medio Ambiental, LEQMA, Departamento de Ciencias del Ambiente, \\ Facultad de Química y Biología, Universidad de Santiago de Chile, USACh, Casilla 40, Correo 33, \\ Santiago, Chile \\ *Laboratori d'Electroquímica dels Materials i del Medi Ambient, Departament de Química Física, \\ Facultat de Química, Universitat de Barcelona, Martí i Franquès 1-11, 08028 Barcelona, Spain
}

Corresponding Author: E-mail: ricardo.salazar@usach.cl; Tel.: +56-2-27181134

Corresponding Author: E-mail: i.sires@ub.edu; Tel.: +34-93-4039243; Fax: +34-93-4021231

Received: July 23, 2014; Published: December 6, 2014

\begin{abstract}
Small volumes $\left(100 \mathrm{~mL}\right.$ ) of acidic aqueous solutions with $30-200 \mathrm{mg} \mathrm{L}^{-1}$ TOC of the toxic azo dye Acid Red 1 (AR1) have been comparatively treated by various electrochemical advanced oxidation processes (EAOPS). The electrolytic system consisted of a BDD anode able to produce ${ }^{\circ} \mathrm{OH}$ and an air-diffusion cathode that generated $\mathrm{H}_{2} \mathrm{O}_{2}$, which subsequently reacted with added $\mathrm{Fe}^{2+}$ to yield additional ${ }^{\circ} \mathrm{OH}$ from Fenton's reaction.

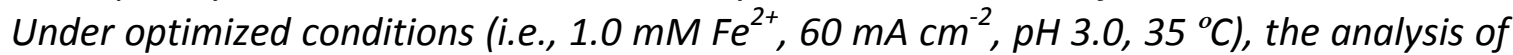
the initial rates for decolourization and AR1 decay assuming a pseudo-first-order kinetics revealed a much higher rate constant for photoelectro-Fenton $\left(P E F, \sim 2.7 \times 10^{-3} \mathrm{~s}^{-1}\right.$ ) compared to electro-Fenton $\left(E F, \sim 0.6 \times 10^{-3} \mathrm{~s}^{-1}\right)$. Mineralization after $180 \mathrm{~min}$ was also greater in the former treatment (90\% vs $63 \%)$. The use of UV radiation in PEF contributed to $\mathrm{Fe}(\mathrm{III})$ photoreduction as well as to photodecarboxylation of refractory intermediates, yielding a mineralization current efficiency as high as $85 \%$ during the treatment of solutions of $200 \mathrm{mg} \mathrm{L}^{-1}$ TOC. Primary reaction intermediates included three aromatic derivatives with the initial naphthalenic structure and four molecules only featuring benzenic rings, which were totally mineralized in PEF.
\end{abstract}

Keywords

Air-diffusion cathode; Azophloxine; boron-doped diamond (BDD); E128; EAOPs; decolourization; food azo dye; mineralization; Red $2 \mathrm{G}$ 


\section{Introduction}

In recent years, great attention has been paid to the electrochemical advanced oxidation processes (EAOPS) based on Fenton's reaction chemistry for water decontamination [1]. Among them, electro-Fenton (EF) and photoelectro-Fenton (PEF) have been the most studied methods for the treatment of waters polluted by organic pollutants such as pharmaceuticals [2-4], pesticides [5-7] and synthetic dyes [8-11] due to their outstanding performance. In EF and $\mathrm{PEF}, \mathrm{H}_{2} \mathrm{O}_{2}$ is continuously electrogenerated in the reaction cell from the two-electron reduction of injected or flushed gaseous $\mathrm{O}_{2}$ as follows [1]:

$$
\mathrm{O}_{2}+2 \mathrm{H}^{+}+2 \mathrm{e}^{-} \rightarrow \mathrm{H}_{2} \mathrm{O}_{2}
$$

The use of carbonaceous cathodes, particularly in the form of gas-diffusion electrodes (GDEs), promotes the production of a high yield of $\mathrm{H}_{2} \mathrm{O}_{2}$ at high rate. Therefore, the current efficiency for reaction (1) on GDEs turns out to be the highest among all tested materials. The activation of $\mathrm{H}_{2} \mathrm{O}_{2}$, which is a weak oxidant, is achieved in the presence of a small amount of metal catalyst, especially $\mathrm{Fe}^{2+}$, at $\mathrm{pH}$ around 3 . Under such conditions, ${ }^{\circ} \mathrm{OH}$ is produced in the bulk from Fenton's reaction (2) [1]:

$$
\mathrm{Fe}^{2+}+\mathrm{H}_{2} \mathrm{O}_{2} \rightarrow \mathrm{Fe}^{3+}+{ }^{\circ} \mathrm{OH}+\mathrm{OH}^{-}
$$

In PEF, the contaminated acidic solution is irradiated with artificial UV light, thus causing: (i) the photoreduction of $\mathrm{Fe}(\mathrm{OH})^{2+}$, which is the main $\mathrm{Fe}^{3+}$ species at $\mathrm{pH} 3$, via photo-Fenton's reaction (3), and (ii) the photodecarboxylation of some Fe(III)-carboxylate complexes, which are quite refractory to oxidation by ${ }^{\circ} \mathrm{OH}$ formed from Fenton's reaction, via reaction (4) [1]. While reaction (3) contributes to form additional ${ }^{\circ} \mathrm{OH}$ as well as to maintain the Fenton's cycle by continuously regenerating $\mathrm{Fe}^{2+}$, reaction (4) makes it possible to reach great mineralization degrees.

$$
\begin{aligned}
& \mathrm{Fe}(\mathrm{OH})^{2+}+h v \rightarrow \mathrm{Fe}^{2+}+{ }^{\circ} \mathrm{OH} \\
& {\left[\mathrm{Fe}(\mathrm{OOCR})^{2+}\right]+h v \rightarrow \mathrm{Fe}^{2+}+\mathrm{CO}_{2}+\mathrm{R}^{\bullet}}
\end{aligned}
$$

For some pollutants, the performance of EF and PEF can be further enhanced by using a large $\mathrm{O}_{2}$-overpotential anode such as boron-doped diamond (BDD). This material favours the electrooxidation (EO) of the organic molecules by action of ${ }^{\circ} \mathrm{OH}$ adsorbed on the anode surface via reaction (5) [12]:

$$
\mathrm{BDD}+\mathrm{H}_{2} \mathrm{O} \rightarrow \mathrm{BDD}\left({ }^{\circ} \mathrm{OH}\right)+\mathrm{H}^{+}+\mathrm{e}^{-}
$$

Acid Red 1 (AR1, also called Amido Naphtol Red G, Red 2G, Food Red 10 or Azophloxine, see chemical structure in Table 1) is a synthetic monoazo dye. Azo dyes constitute the most comprehensive and varied family among all synthetic organic dyes available in the industry for dyeing all kinds of fabrics [13]. Until 2007, AR1 was the preferred dye for baby food colouring due to the resulting intense red colour, but the Scientific Panel of the European Food Safety Authority (EFSA) on food additives, flavourings, processing aids and materials in contact with food was then asked to re-evaluate this dye due to food safety concerns related to its high toxicity and carcinogenic effects [14]. Based on this report, the European Union has agreed with its suspension as food colouring, as published in the Official Journal [15]. Not surprisingly, it is also banned in other countries outside Europe.

At present, it is known that AR1 is extensively metabolized to aniline, it may interfere with blood haemoglobin and it is suspected of being a carcinogen [16]. It is therefore one of the dyes 
that the hyperactive children's support group recommends to be eliminated from the diet of children. In contrast, AR1 has become one the most used dyes in Chile and over the world for dyeing polyester-, nylon-, cellulose- and acrylic-based fibers. Consequently, if such industrial wastewaters are not conveniently treated before discharge, their impact on the surrounding ecosystems may be dramatic.

Some few studies have focused on the fate of AR1 upon application of non-electrochemical advanced oxidation processes (AOPs) [17-19]. Regarding the electrochemical technology, only its electrochemical reduction on an activated carbon fiber cathode has been reported [20], but as far as we are concerned its removal by EF and PEF with BDD or other anodes has not been reported yet. These latter processes are of great interest for the removal of food azo dyes, as some of us recently demonstrated for the treatment of Tartrazine solutions [21].

In this work, the decolourization, AR1 decay and mineralization profiles resulting from the treatment of synthetic aqueous solutions of $100 \mathrm{~mL}$ of AR1 by several EAOPs have been investigated. BDD and GDE, both of $2.5 \mathrm{~cm}^{2}$, have been used at constant current upon addition of $50 \mathrm{mM} \mathrm{Na} 2 \mathrm{SO}_{4}$ as supporting electrolyte at $\mathrm{pH}$ 3. The optimization of iron catalyst concentration and applied current has preceded the treatment of solutions with up to $200 \mathrm{mg} \mathrm{L}^{-1} \mathrm{TOC}$ content by PEF. In addition, chromatographic analyses allowed the identification of aliphatic and cyclic byproducts formed during the cleavage of the AR1 structure.

\section{Experimental}

\section{Chemicals}

AR1 (disodium 8-acetamido-1-hydroxy-2-phenylazonaphthalene-3,6-disulfonate, $\mathrm{C}_{18} \mathrm{H}_{13} \mathrm{~N}_{3} \mathrm{Na}_{2} \mathrm{O}_{8} \mathrm{~S}_{2}$, $\mathrm{Cl}$ 18050, 60\% purity) was purchased from Sigma-Aldrich. Anhydrous sodium sulfate used as background electrolyte and iron(II) sulfate heptahydrate used as catalyst in EF and PEF were of analytical grade from Merck. Solutions were prepared with bidistilled water and their $\mathrm{pH}$ was adjusted to 3 before the electrolyses with analytical grade sodium hydroxide or sulfuric acid from Merck. Other chemicals were obtained from Merck and Sigma-Aldrich.

\section{Electrolytic system}

The electrolyses were performed in an open, undivided cell containing a $100 \mathrm{~mL}$ solution and featuring a double jacket for circulation of external thermostated water at $35{ }^{\circ} \mathrm{C}\left(\right.$ WiseCircu ${ }^{\circledR}$ WCB-11 water bath). The solution was stirred with a magnetic bar at $800 \mathrm{rpm}$ to ensure good mixing and transport of reactants. The cell contained a $2.5 \mathrm{~cm}^{2} \mathrm{Si} / \mathrm{BDD}$ thin-film electrode from Adamant $^{\oplus}$ (500 ppm B) as the anode and a $2.5 \mathrm{~cm}^{2}$ carbon-PTFE air-diffusion cathode from Electrocell ${ }^{\circledR}$. The cathode was fed with compressed air flowing at $1 \mathrm{~L} \mathrm{~min}^{-1}$ for $\mathrm{H}_{2} \mathrm{O}_{2}$ generation. The trials were performed at constant current provided by an MCP M10-QD305 power supply. In PEF, the solution was irradiated with a Black Ray B100AP lamp.

\section{Equipment and analytical procedures}

The solution $\mathrm{pH}$ was measured on an Extech $321990 \mathrm{pH}$-meter. Samples withdrawn at regular time intervals from electrolyzed solutions were neutralized at $\mathrm{pH} 7-8$ to stop the degradation process and filtered with $0.45 \mu \mathrm{m}$ PTFE filters from Whatman before analysis. The decolourization of AR1 solutions was monitored from the absorbance $(A)$ decay at the maximum visible wavelength $\left(\lambda_{\max }\right)$ of $520 \mathrm{~nm}$, measured from the spectra recorded on a Cary $1 \mathrm{E} U \mathrm{~V} / \mathrm{Vis}$ spectrophotometer (Varian). The percentage of colour removal or decolourization efficiency was then determined as follows [21]: 
Colour removal, $\%=100 \frac{A_{0}-A_{\mathrm{t}}}{A_{0}}$

where $A_{0}$ and $A_{t}$ denote the absorbance at initial time and after an electrolysis time $t$, respectively.

The mineralization of solutions was monitored from their total organic carbon (TOC) abatement, determined on a Vario TOC Select analyzer. From these data, the mineralization current efficiency (MCE) at a given current ( / / A) and electrolysis time $(t / h)$ were estimated as follows [1]:

$$
\text { MCE, } \%=100 \frac{n F V_{s} \Delta(T O C)_{\text {exp }}}{4.32 \times 10^{7} \mathrm{~m} / \mathrm{t}}
$$

where $F$ is the Faraday constant $\left(96487 \mathrm{C} \mathrm{mol}^{-1}\right), V_{s}$ is the solution volume (L), $\Delta(\text { TOC) })_{\exp }$ is the experimental TOC decay $\left(\mathrm{mg} \mathrm{L}^{-1}\right), 4.32 \times 10^{7}$ is a conversion factor $\left(3600 \mathrm{~s} \mathrm{~h}^{-1} \times 12000 \mathrm{mg} \mathrm{mol}^{-1}\right)$ and $m$ is the number of carbon atoms of AR1 (18 atoms). The number of electrons $(n)$ consumed per each dye molecule was taken as 98 considering that its mineralization leads to carbon dioxide and nitrate and sulfate ions as follows:

$$
\mathrm{C}_{18} \mathrm{H}_{13} \mathrm{~N}_{3} \mathrm{Na}_{2} \mathrm{O}_{8} \mathrm{~S}_{2}+45 \mathrm{H}_{2} \mathrm{O} \rightarrow 18 \mathrm{CO}_{2}+3 \mathrm{NO}_{3}{ }^{-}+2 \mathrm{SO}_{4}{ }^{2-}+2 \mathrm{Na}^{+}+103 \mathrm{H}^{+}+98 \mathrm{e}^{-}
$$

AR1 decay was followed by reversed-phase high performance liquid chromatography (HPLC) with a Waters 625 LC fitted with a Hibar ${ }^{\circledR}$ RP-18e $5 \mu \mathrm{m}, 150 \times 4 \mathrm{~mm}$, column at $25{ }^{\circ} \mathrm{C}$ and coupled with a photodiode array detector set at $\lambda=520 \mathrm{~nm}$. The mobile phase was a 70:30 (v/v) acetonitrile/1.0 mM ammonium acetate $(\mathrm{pH} 4)$ mixture at $0.5 \mathrm{~mL} \mathrm{~min}^{-1}$. Generated carboxylic acids were detected by ion-exclusion HPLC using the same LC fitted with a Bio-Rad Aminex HPX 87H, $300 \times 7.8 \mathrm{~mm}$, column at $25{ }^{\circ} \mathrm{C}$ and setting the array detector at $\lambda=210 \mathrm{~nm}$. The isocratic elution at $0.6 \mathrm{~mL} \mathrm{~min}^{-1}$ with $4 \mathrm{mM} \mathrm{H}_{2} \mathrm{SO}_{4}$ as the mobile phase yielded good peaks for maleic $\left(t_{\mathrm{r}}=8.8 \mathrm{~min}\right)$, oxamic $\left(t_{r}=10.6 \mathrm{~min}\right)$, malic $\left(t_{r}=11.3 \mathrm{~min}\right)$, formic $\left(t_{r}=14.9 \mathrm{~min}\right)$ and acetic $\left(t_{\mathrm{r}}=16.1 \mathrm{~min}\right)$.

The cyclic and/or aromatic intermediates were analyzed by gas chromatography coupled to mass spectrometry (GC-MS). Several electrolyses were carried out under different experimental conditions for short and long times. The final solutions were collected together until reaching $500 \mathrm{~mL}$, which were then extracted three times with $30 \mathrm{~mL} \mathrm{CH}{ }_{2} \mathrm{Cl}_{2}$. The resulting organic solution $\left(90 \mathrm{~mL}\right.$ ) was dried with anhydrous $\mathrm{Na}_{2} \mathrm{SO}_{4}$, then filtered and completely evaporated in a rotary to obtain a pale yellow solid that was further analyzed.

\section{Results and Discussion}

Influence of the experimental parameters on the degradation of Acid Red 1 by EF process

Solutions containing $300 \mathrm{mg} \mathrm{L}^{-1}$ AR1 (i.e., $0.59 \mathrm{mM}$ AR1 or $100 \mathrm{mg} \mathrm{L}^{-1} \mathrm{TOC}$ ) were electrolyzed at $60 \mathrm{~mA} \mathrm{~cm}^{-2}$ in the presence of different amounts of $\mathrm{Fe}^{2+}$ as catalyst. As can be seen in Fig. 1, the absence of $\mathrm{Fe}^{2+}$ (so-called EO process) caused the slowest decolourization and TOC abatement, only reaching $70 \%$ colour removal after $70 \mathrm{~min}$ and $25 \%$ TOC decay after $180 \mathrm{~min}$. Under the present $\mathrm{EO}$ conditions, given the weak oxidation power of $\mathrm{H}_{2} \mathrm{O}_{2}$, the organic matter can be mainly degraded by $\operatorname{BDD}\left({ }^{\circ} \mathrm{OH}\right)$ formed via reaction (5). This radical tends to be very active towards the initial pollutants and their by-products because it is weakly physisorbed on the anode surface and it is generated at a very positive potential. Moreover, it is known that hydroxyl radicals can react at high rate with all double bonds in the aromatic rings and, especially, with the $-\mathrm{N}=\mathrm{N}-$ bond. However, since $\operatorname{BDD}\left({ }^{\circ} \mathrm{OH}\right)$ is confined to the anode vicinity, the degradation process becomes 
severely limited by mass transport, thus being needed a much longer electrolysis time to effectively destroy the molecules in a batch system without recirculation like the one tested here.

In contrast to the previous finding, within the same time period the presence of $\mathrm{Fe}^{2+}$ allowed the complete decolourization as well as a greater mineralization in all cases, which can be accounted for by the crucial contribution of ${ }^{\circ} \mathrm{OH}$ formed in the bulk from Fenton's reaction (2). As can be seen in Fig. 1a, the increase in $\mathrm{Fe}^{2+}$ concentration from 0.1 to 0.5 and then to $1.0 \mathrm{mM}$ clearly accelerated the colour removal, being necessary 70,60 and $40 \mathrm{~min}$, respectively, to get colourless solutions.
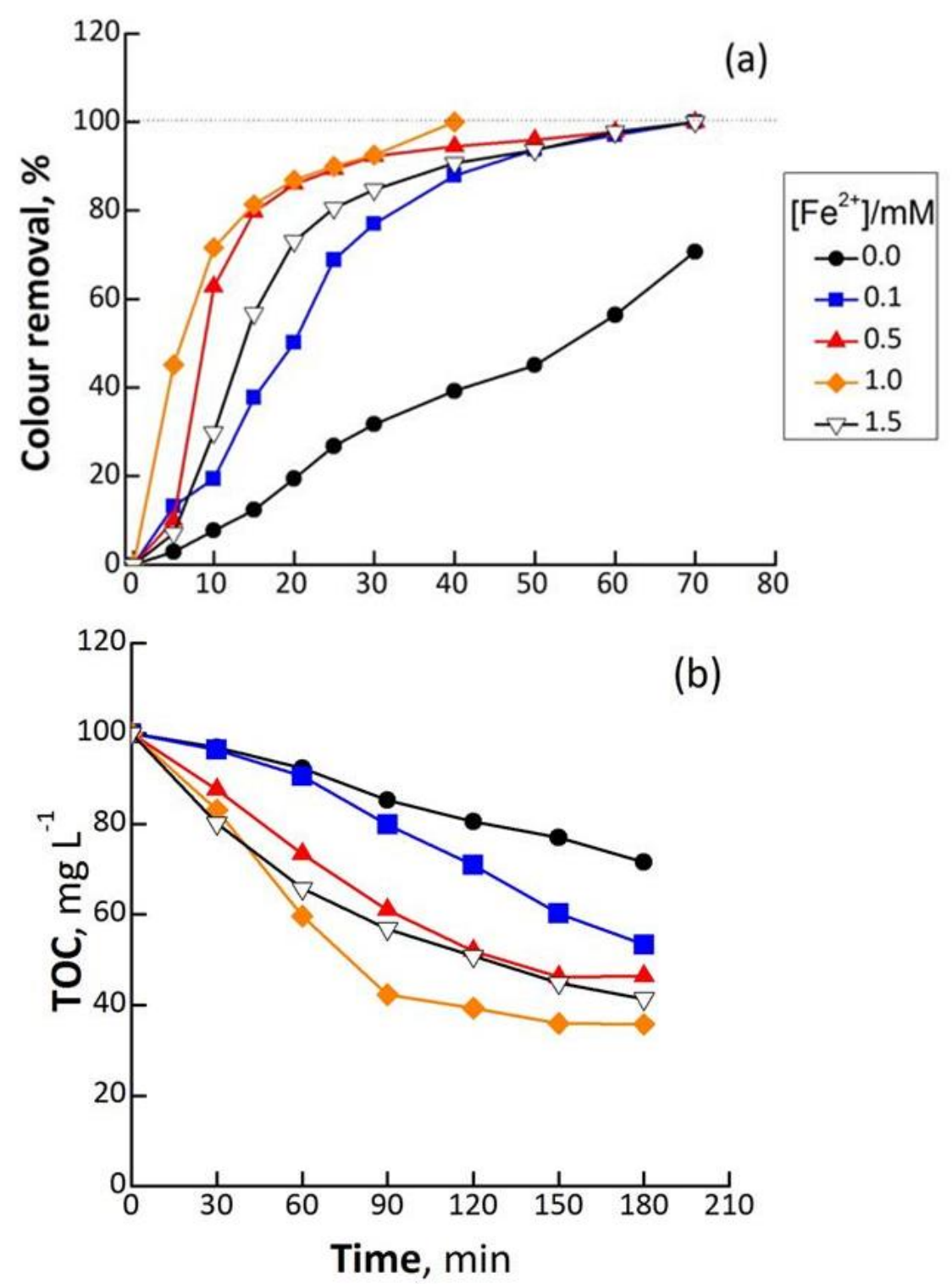

Figure 1. Effect of $\mathrm{Fe}^{2+}$ concentration on (a) decolourization efficiency at $520 \mathrm{~nm}$ and (b) TOC removal with electrolysis time for the electro-Fenton treatment of solutions of $300 \mathrm{mg} \mathrm{L}^{-1} \mathrm{AR} 1$ in $0.05 \mathrm{M} \mathrm{Na}_{2} \mathrm{SO}_{4}$ at $\mathrm{pH} 3.0,35{ }^{\circ} \mathrm{C}$ and $60 \mathrm{~mA} \mathrm{~cm}{ }^{-2}$.

The rising catalyst content had a positive effect on the mineralization profiles as well, since 47, 54 and $63 \%$ TOC removal was attained after 180 min using $0.1,0.5$ and $1.0 \mathrm{mM} \mathrm{Fe}^{2+}$. In contrast, further increase to $1.5 \mathrm{mM}$ was detrimental, eventually leading to slower colour removal and only $59 \%$ TOC abatement at $180 \mathrm{~min}$. This phenomenon can be mainly explained by the larger extent of parasitic reactions causing the consumption of ${ }^{\bullet} \mathrm{OH}$, particularly by $\mathrm{Fe}^{2+}$. It must be noted that the mineralization was always partial, with a tendency to reach a plateau owing to the plausible 
accumulation of refractory intermediates (as confirmed later on) that could not be oxidized by ${ }^{\bullet} \mathrm{OH}$ in the bulk and were very slowly destroyed by $\mathrm{BDD}\left({ }^{\circ} \mathrm{OH}\right)$. In conclusion, $1.0 \mathrm{mM}$ was chosen as the optimum $\mathrm{Fe}^{2+}$ concentration for subsequent tests.

The effect of current density within the range $8-80 \mathrm{~mA} \mathrm{~cm}$, carried out under conditions shown in Fig. 1 with $1 \mathrm{mM} \mathrm{Fe}{ }^{2+}$ as the optimized amount, is depicted in Fig. 2 . These trials aimed at exploring the possibility of enhancing the decolourization and mineralization kinetics, which is based on the fact that the applied current determines the yield of $\operatorname{BDD}\left({ }^{\circ} \mathrm{OH}\right)$ formed via reaction (5) as well as that of ${ }^{\circ} \mathrm{OH}$ via reaction (2) because it depends on the $\mathrm{H}_{2} \mathrm{O}_{2}$ formation rate and $\mathrm{Fe}^{2+}$ regeneration rate.
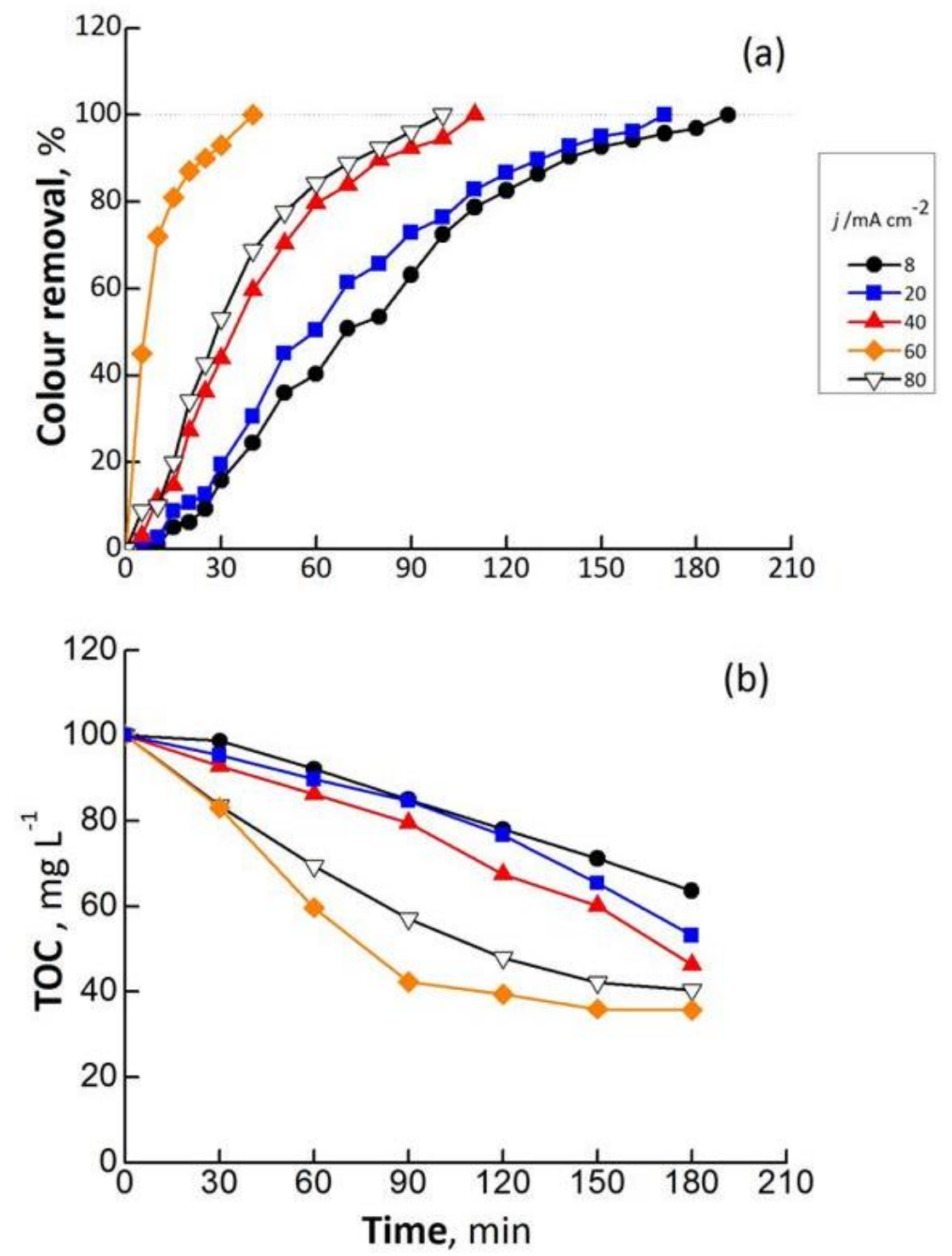

Figure 2. Effect of current density on (a) decolourization efficiency at $520 \mathrm{~nm}$ and (b) TOC removal with electrolysis time for the electro-Fenton treatment of solutions of $300 \mathrm{mg} \mathrm{L}^{-1}$ AR1 in $0.05 \mathrm{M} \mathrm{Na}_{2} \mathrm{SO}_{4}$ with $1.0 \mathrm{mM} \mathrm{Fe} e^{2+}$ at $\mathrm{pH} 3.0$ and $35{ }^{\circ} \mathrm{C}$.

A progressive increase in current density from 8 to $60 \mathrm{~mA} \mathrm{~cm}{ }^{-2}$ caused the acceleration of both, decolourization and mineralization. This can be easily explained by the faster generation of $\mathrm{BDD}\left({ }^{\circ} \mathrm{OH}\right)$ on the anode and ${ }^{\circ} \mathrm{OH}$ in the bulk. Note that even the lowest current densities were able to yield the complete decolourization at long electrolysis time. However, further increase to $80 \mathrm{~mA} \mathrm{~cm}^{-2}$ was detrimental since it caused a slower colour removal and led to a lower TOC 
removal. This negative effect arises from the shift in cathode potential to unfavourable values that promoted the reduction of $\mathrm{O}_{2}$ to $\mathrm{H}_{2} \mathrm{O}$ over reaction (1) and hindered the conversion of $\mathrm{Fe}^{3+}$ to $\mathrm{Fe}^{2+}$. As a matter of fact, $\mathrm{H}_{2} \mathrm{O}_{2}$ concentration analyzed during the electrolyses at 60 and $80 \mathrm{~mA} \mathrm{~cm}^{-2}$ reached $25 \mathrm{mM}$ and $15 \mathrm{mM}$, respectively. Thus, $60 \mathrm{~mA} \mathrm{~cm}^{-2}$ was chosen as the optimum value.

\section{Effect of UVA light}

As discussed in the Introduction, for most of the contaminated solutions studied in the past it was possible to enhance the degradation process by irradiating them with UV light, which favoured the oxidation of pollutants and their by-products due to the action of reaction (3) and (4). In the present study, no direct photolysis of AR1 by UV light was observed, since its peak during the HPLC analyses remained unchanged. This ensured the photostability of AR1 during the electrolyses run under PEF conditions. For this purpose, the AR1 solutions were treated as done in the previous EF experiments but incorporating the UV lamp near the cell.

As shown in Fig. 3a, solutions of $300 \mathrm{mg} \mathrm{L}^{-1}$ AR1 treated by PEF under the optimized conditions described before (i.e., $1.0 \mathrm{mM} \mathrm{Fe}^{2+}$ and $60 \mathrm{~mA} \mathrm{~cm}^{-2}$ ) were more quickly decolourized compared to EF trials, being required $50 \mathrm{~min}$ instead of $60 \mathrm{~min}$ to become colourless (see Fig. 1a for comparison). The key contribution of photoreduction reaction (3) favoured the faster regeneration of $\mathrm{Fe}^{2+}$, which then was able to accelerate the production of ${ }^{\circ} \mathrm{OH}$ from reaction (2). On the other hand, PEF also yielded a much larger mineralization after $180 \mathrm{~min}$, reaching $90 \%$ owing to photodecarboxylation reaction (4). As reported elsewhere [1], some of the reaction intermediates can form stable complexes with Fe(III) that can be effectively degraded only upon action of UV photons since ${ }^{\circ} \mathrm{OH}$ and $\mathrm{BDD}\left({ }^{\circ} \mathrm{OH}\right)$ are much less effective. Fig. 3a also depicts the decay of AR1 monitored by HPLC during the same experiment. Its profile is quite similar to colour removal profile, which means that no other coloured by-products were formed during the treatment. Assuming a pseudo-first-order kinetics, an apparent rate constant $\left(k_{\text {app }}\right)$ of $2.74 \times 10^{-3} \mathrm{~s}^{-1}$ for AR1 decay was determined. The decay of the dye was also similar to the colour removal trend for EF treatment (not shown), revealing a much smaller $k_{\mathrm{app}}=0.59 \times 10^{-3} \mathrm{~s}^{-1}$. Therefore, the beneficial synergy between ${ }^{\circ} \mathrm{OH}, \mathrm{BDD}\left({ }^{\circ} \mathrm{OH}\right)$ and UV light for the decontamination of AR1 solutions is demonstrated.

Due to production needs, actual wastewaters may present a significant variation in the dye content over time and thus, it is mandatory that the water treatment technology is flexible enough to be adapted to such changes. The effect of AR1 concentration on the mineralization profile vs. time is shown in Fig. 3b. A similar TOC removal was attained after $180 \mathrm{~min}$ for solutions containing 30 and $100 \mathrm{mg} \mathrm{L}^{-1}$ TOC. In contrast, only $75 \%$ mineralization was reached for solutions with $200 \mathrm{mg} \mathrm{L}^{-1}$ TOC, which is simply due to the much larger number of organic molecules to be degraded in the latter case. But, an important feature to be highlighted is the progressively increasing slope of the curves (i.e., larger mineralization rate) upon increase of AR1 concentration, which can be related to the more efficient reaction between ${ }^{\circ} \mathrm{OH} / \mathrm{BDD}\left({ }^{\circ} \mathrm{OH}\right)$ and the organic molecules. Indeed, low AR1 concentrations cause the waste of radicals in self-destruction and other side reactions, whereas high organic contents lead to effective oxidation reactions. This is clearly demonstrated in Fig. 3c, which compares the evolution of MCE vs time for several EAOPs. For solutions with $100 \mathrm{mg} \mathrm{L}^{-1} \mathrm{TOC}$, the efficiency increases in the sequence $\mathrm{EO}<\mathrm{EF}<\mathrm{PEF}$, with maximum values of 10,25 and $55 \%$, respectively. As discussed before, this can be related to the more favorable synergy between different oxidants in the case of PEF. In addition, a greater MCE resulted from the treatment of larger AR1 concentrations in PEF, reaching $85 \%$ during the 
treatment of $200 \mathrm{mg} \mathrm{L}^{-1} \mathrm{TOC}$, thus confirming the lower extent of parasitic reactions that cause radical waste. Note that MCE tends to decrease at long electrolyses time, which can be explained by (i) the formation of more resistant intermediates and (ii) the mass transport limitations related to low organic loads.
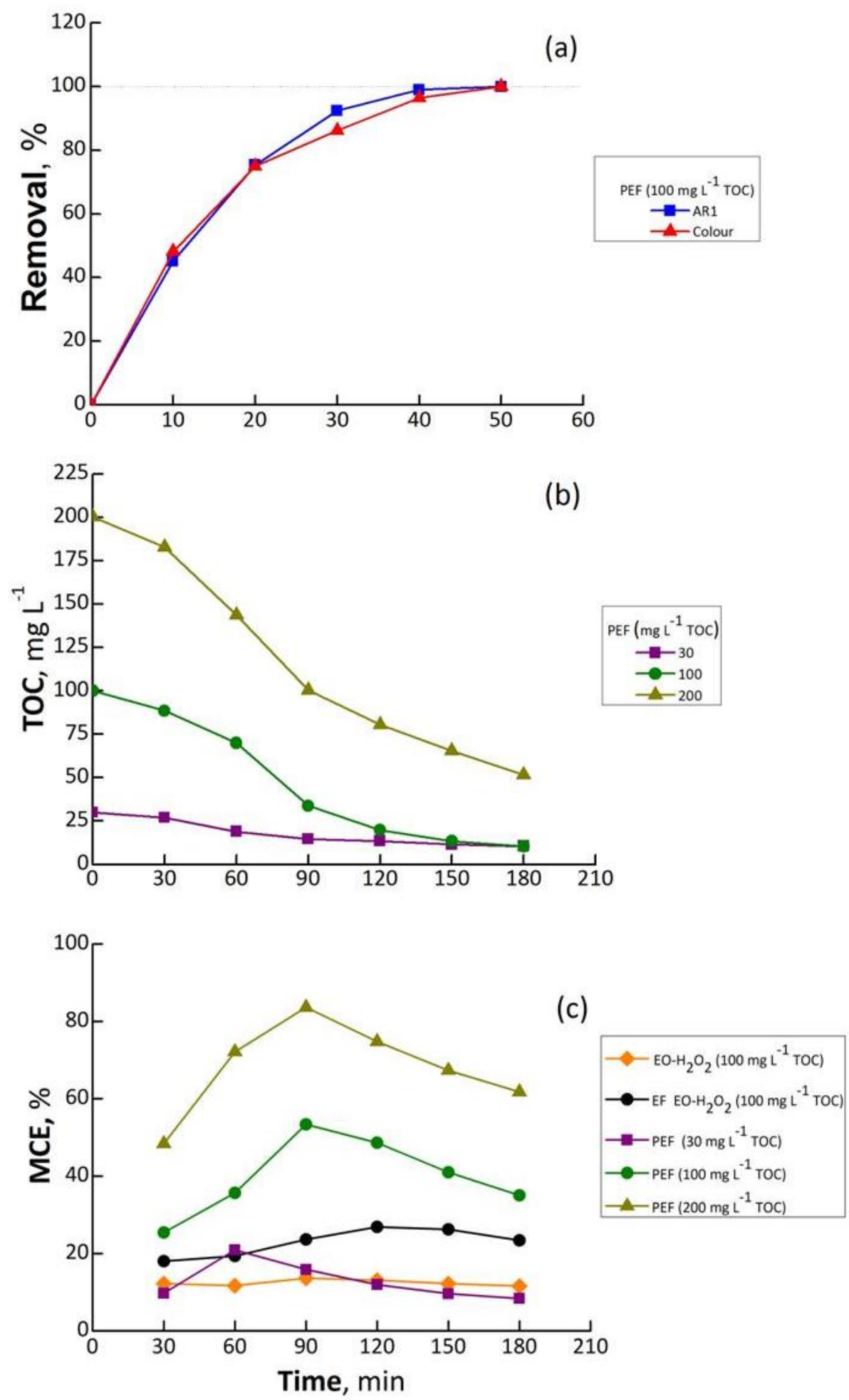

Figure 3. (a) Decolourization efficiency at $520 \mathrm{~nm}$ and percentage of AR1 removal with electrolysis time for the photoelectro-Fenton treatment of solutions of $300 \mathrm{mg} \mathrm{L}^{-1} \mathrm{AR} 1 \mathrm{in}$ $0.05 \mathrm{M} \mathrm{Na}_{2} \mathrm{SO}_{4}$ with $1.0 \mathrm{mM} \mathrm{Fe} e^{2+}$ at $\mathrm{pH} 3.0,35{ }^{\circ} \mathrm{C}$ and $60 \mathrm{~mA} \mathrm{~cm}{ }^{-2}$. (b) TOC abatement vs. time for the same experiment compared to trials at different AR1 concentrations. (c) MCE for trials shown in (b) compared to EO (O $\left.\mathrm{mM} \mathrm{Fe}{ }^{2+}\right)$ and EF $\left(1.0 \mathrm{mM} \mathrm{Fe}^{2+}\right)$ treatments shown in Fig. 1 b. 


\section{Identification of reaction intermediates}

Table 1 summarizes the seven aromatic intermediates identified during PEF treatments.

Table 1. Structures of Acid Red 1 and its degradation intermediates identified by GC-MS analysis.

\begin{tabular}{llc}
\hline Chemical name & Structure & $\mathrm{m} / \mathbf{z}$ \\
\hline
\end{tabular}

\section{Acid Red 1}

Naphthalene derivatives

Disodium 8-acetamido-1-hydroxy-2-(4-

hydroxyphenylazo)naphthalene-3,6-disulfonate

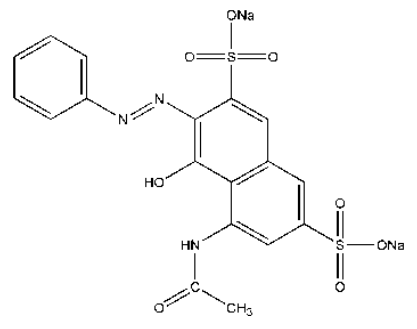

Disodium 1,2-dihydroxy-3-

phenylazonaphthalene-4,7-disulfonate

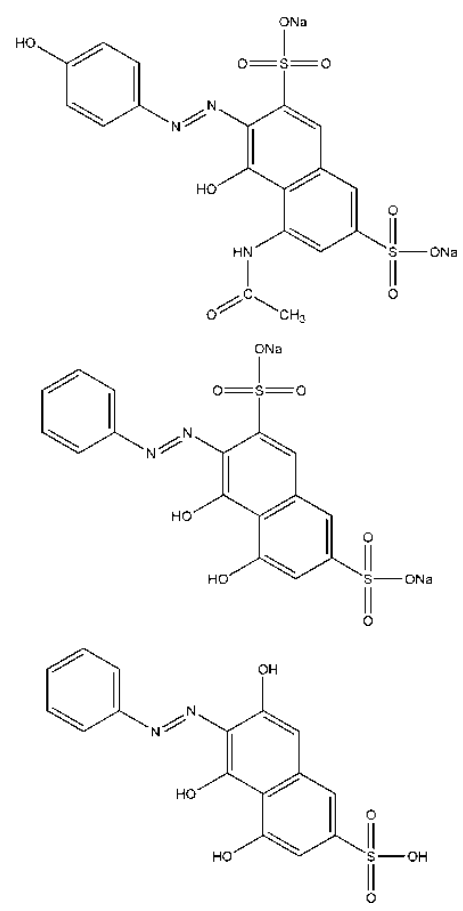

524.12

468.37

(5-Phenylazo-3,4,6-

trihydroxynaphthalene)sulfonic acid

\section{Benzene derivatives}

Sodium (3,5-dihydroxy-2-

phenylazo)benzenesulfonate

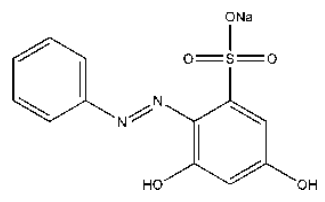

Sodium (1-hydroxy-2-[4-hydroxyphenylazo]-2oxo)ethanesulfonate

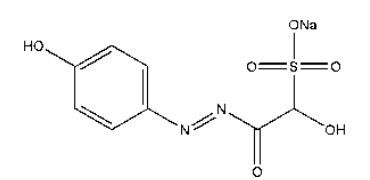

2-(3,5-dihydroxyphenylazo)-1-hydroxy-2-oxoethanesulfonic acid

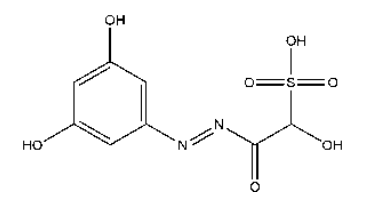

Hydroquinone<smiles>Cc1ccc(C)cc1</smiles> 
As can be seen, ${ }^{\circ} \mathrm{OH}$ and $\mathrm{BDD}\left({ }^{\circ} \mathrm{OH}\right)$ led to the hydroxylation of the benzenic and naphthalenic rings of AR1 to yield three naphthalene derivatives. The subsequent action of radicals onto AR1 and/or onto those intermediates led to the formation of four benzene derivatives. The accumulation of these aromatic intermediates would be dangerous due to their inherent high toxicity and thus, PEF treatments had to be prolonged until their complete disappearance.

The progressive cleavage and oxidation of the aromatic intermediates gave rise to the formation of short-chain aliphatic carboxylic acids, as also described elsewhere for other pollutants [22]. Five $\mathrm{C}_{1}-\mathrm{C}_{4}$ acids were identified by ion-exclusion HPLC, namely maleic, oxamic, malic, formic and acetic. As explained from Fig. 3, PEF ensured the almost complete removal of all these acids since the TOC in the final solutions was $<10 \%$ after $180 \mathrm{~min}$.

\section{Conclusions}

PEF technology is confirmed as a very powerful alternative for giving response to environmental concerns related to water contamination by organic pollutants. This process allows a much faster destruction of AR1 as well as a more significant and efficient TOC removal compared to EO and EF, thus becoming a promising technology for the treatment of industrial wastewaters containing this azo dye. The toxic intermediates formed during the first degradation stages are completely transformed into aliphatic molecules, which are slowly converted to $\mathrm{CO}_{2}$ and $\mathrm{H}_{2} \mathrm{O}$. The use of renewable energy such us sunlight in sunny countries like Chile and Spain, giving rise to the socalled solar photoelectro-Fenton (SPEF) process, would be an interesting feature for real-scale application.

Acknowledgements: The authors thank CONICYT (Chile) for support under FONDECYT grant 1130391 and DICYT-USACh, as well as for the PhD fellowship N²1130071 awarded to C. GonzálezVargas.

\section{References}

[1] E. Brillas, I. Sirés, M. A. Oturan, Chemical Reviews 109 (2009) 6570-6631

[2] A. Dirany, S. Efremova Aaron, N. Oturan, I. Sirés, M. A Oturan, J. J. Aaron, Analytical and Bioanalytical Chemistry 400 (2011) 353-360

[3] A. El-Ghenymy, N. Oturan, M. A. Oturan, J.A. Garrido, P. L. Cabot, F. Centellas, R. M. Rodríguez, E. Brillas, Chemical Engineering Journal 234 (2013) 115-123

[4] S. Loaiza-Ambuludi, M. Panizza, N. Oturan, A. Özcan, M. A. Oturan, Journal of Electroanalytical Chemistry 702 (2013) 31-36

[5] N. Oturan, M. Zhou, M. A. Oturan, Journal of Physical Chemistry A 114 (2010) 10605-10611

[6] R. Salazar, M. S. Ureta-Zañartu, Water Air Soil Pollution 223 (2012) 4199-4207

[7] J. Urzúa, C. González-Vargas, F. Sepúlveda, M. S. Ureta-Zañartu, R. Salazar, Chemosphere 93 (2013) 2774-2781

[8] M. Zhou, Q. Yu, L. Lei, Dyes and Pigments 77 (2008) 129-136

[9] M. Panizza, M. A. Oturan, Electrochimica Acta 56 (2011) 7084-7087

[10] E. J. Ruiz , A. Hernández-Ramírez, J. M. Peralta-Hernández, C. Arias, E. Brillas, Chemical Engineering Journal 171 (2011) 385-392

[11] R. Salazar, E. Brillas, I. Sirés, Applied Catalysis B: Environmental 115-116 (2012) 107-116

[12] M. Panizza, G. Cerisola, Chemical Reviews 109 (2009) 6541-6569

[13] C. A. Martínez-Huitle, E. Brillas, Applied Catalysis B: Environmental 87(2009) 105-145

[14] European Food Safety Authority, The EFSA Journal 515 (2007) 1-28 
[15] Official Journal of the European Union L 195/8, 27.7.2007. Commission regulation (EC) No $884 / 2007$ of July 2007 on emergency measures suspending the use of E 128 Red $2 \mathrm{G}$ as food colour

[16] A. F. Villa, F. Conso, EMC - Toxicologie-Pathologie 1 (2004) 161-177

[17] Cs. M. Földváry, L. Wojnárovits, Radiation Physics and Chemistry 78 (2009) 13-18

[18] N. K. Daud, M.A. Ahmad, B.H. Hameed, Chemical Engineering Journal 165 (2010) 111-116

[19] S. Thomas, R. Sreekanth, V. A. Sijumon, U. K. Aravind, C. T. Aravindakumar, Chemical Engineering Journal 244 (2014) 473-482

[20] Z. Shen, W. Wang, J. Jia, J. Ye, X. Feng, A. Peng, Journal of Hazardous Materials B84 (2001) 107-116.

[21] A. Thiam, M. Zhou, E. Brillas, I. Sirés, Applied Catalysis B: Environmental 150-151(2014) 116-125

[22] M. A. Oturan, M. Pimentel, N. Oturan, I. Sirés, Electrochimica Acta 54 (2008) 173-182

(C) 2014 by the authors; licensee IAPC, Zagreb, Croatia. This article is an open-access article distributed under the terms and conditions of the Creative Commons Attribution license (http://creativecommons.org/licenses/by/3.0/) (cc) EY 